\title{
Extraction, purification and identification of surface adhesion ligand from Lactobacillus
}

\author{
Xue-Yan Lin, Zhong-Hua Wang ${ }^{*}$, Zhong-Xiang Niu ${ }^{*}$, Jun Peng \\ College of Animal Science \& Technology, Shandong Agriculture University, Tai'an, China \\ Email: linxueyan@sdau.edu.cn, ${ }^{*}$ zhwang@,sdau.edu.cn, ${ }^{*}$ zxniu@sdau.edu.cn
}

Received 8 March 2012; revised 12 April 2012; accepted 9 May 2012

\begin{abstract}
The objective of this experiment was to purify and analyze adhesion protein from the surface of Lactobacillus. The surface adhesion ligand of Lactobacillus was isolated with of $\mathrm{LiCl}$ method and $\left(\mathrm{NH}_{4}\right)_{2} \mathrm{SO}_{4}$ method, followed by sephadex chromatography, analyzed with discontinuous native polyacrylamide gel electrophoresis, and tested with a binding assay with intestinal epithelial cells. We get the adhesion matter by two methods: ammonium sulfate and $\mathrm{LiCl}$ extraction. Further purification with sephadex chromatography produced 3 components. The second component of eluted from chromatography had adhesion enhancing ability compared with the control. A single band was present in discontinuous native-poly-acrylamide gel electrophoresis analysis and molecular weight was determined to be 43 - $66 \mathrm{KDa}$. The purified adhesion ligand can improve the number of Lactobacillus adhering to the intestinal epithelial cells.
\end{abstract}

Keywords: Lactobacillus; Adhesion Ligand; Purify; Molecular Weight

\section{INTRODUCTION}

Under normal physiological conditions, the lumen surface of animal small intestine is colonized by a large amount of bacteria, forming a bacterial biofilm. The biofilm is very important for animal immunity, defense, and nutrient absorption. When animals suffer from diseases such as diarrhea, the normal interaction between the host and bacteria is destroyed, causing disturbance of gastrointestinal microflora. The adhesion of normal bacteria to epithelium is mediated by the interaction between adhesion factor (ligand) from normal bacteria and the receptor from the surface of epithelial cells. Using advanced protein isolation, purification and identification technologies, we successfully isolated a adhesion ligand from

*Corresponding authors.
Lactobacillus that colonizes the gastrointestinal tract of chickens, determined the molecular weight. These results provided material and technical resources for the study of the structure of Lactobacillus adhesion ligand, its gene, and the mechanism of adhesion. These results also provided useful information for the development of animal microecology.

\section{MATERIALS AND METHODS}

\subsection{Materials}

\subsubsection{Intestinal Epithelial Cells}

$\mathrm{CaCo}-2$ cells were purchased from Shanghai Institute of Cell Biology.

Cell culture: cells were cultured with DMEM (pH 7.0 - 7.2, Invitrogen) supplemented with $10 \%$ calf serum (Beijing Dingguo Biotechnology Inc.), 1000 IU/L penicillin, $100 \mu \mathrm{g} / \mathrm{L}$ streptomycin, in an incubator with $\mathrm{CO}_{2}$ maintained at $5 \%$. When sufficiently attached to the culture flask, cells were washed with phosphate buffered solution ( $\mathrm{pH} 7.4)$, digested with digestion solution $(0.02 \%$ EDTA:D-Hanks solution $=10: 1$, without $\mathrm{Ca}^{2+}$ and $\mathrm{Mg}^{2+}$ ) for $20-30 \mathrm{~min}$. The digestion was stopped before cells detaching from the culture flask by inverting the flask for 3 min. Digestion solution was removed, and 10\% DMEM (DMEM containing $10 \%$ calf serum) was added to the flask, mixed thoroughly, split to new flasks.

\subsubsection{Lactobacillus}

Lactobacillus (SDnA) was isolated from SPF chicken, provided by Microbiology Laboratory of Shandong Agriculture University.

\subsubsection{Protein Chromatography System}

REC5004V $\mathrm{V}_{18}$ system was purchased from Phamarcia (Sweden).

\subsubsection{Spectrophotometer}

UV-2000 spectrophotometer was purchased from Unico (Shanghai) Instrument Inc. 


\subsection{Methods}

\subsubsection{Culture of Lactobacillus}

MRS medium was used.

\subsubsection{Extraction of Adhesion Ligand}

\subsubsection{Saturated Ammonium Sulfate Method}

Supernatant $(5000 \mathrm{ml})$ of Lactobacillus culture was collected after spinning $5000 \mathrm{rpm}$ at $4^{\circ} \mathrm{C}$ for $15 \mathrm{~min}$, mixed with saturated $\left(\mathrm{NH}_{4}\right)_{2} \mathrm{SO}_{4}$ solution [1,2] until the final concentration was $30 \%$. After setting overnight at $4{ }^{\circ} \mathrm{C}$, the solution was spun $8000-10,000 \mathrm{rpm}$ at $4^{\circ} \mathrm{C}$ for 10 $\mathrm{min}$. The pellet was dissolved in $0.01 \mathrm{~mol} / \mathrm{L}$ phosphate buffered solution ( $\mathrm{pH}$ 7.4), dialyzed in $\mathrm{pH} 7.4$ phosphate buffered solution to remove ions of $\left(\mathrm{NH}_{4}\right)_{2} \mathrm{SO}_{4}$. Then, the sample was concentrated to $1 \mathrm{ml}$ with PEG-6000, measured for OD260 and OD280 to calculate the concentration. The preparation was stored at $-20^{\circ} \mathrm{C}$ until use $[3,4]$.

\subsubsection{LiCl Method}

Suspension of overnight anaerobic bacterial culture was transferred to $500 \mathrm{ml}$ of fresh MRS medium, cultured until $\mathrm{OD}_{600}$ was 1.0. Bacteria were collected after spinning $6000 \mathrm{rpm}$ at $4^{\circ} \mathrm{C}$ for $10 \mathrm{~min}$, washed twice with $10 \mathrm{mM}$ phosphate buffered solution ( $\mathrm{pH}$ 7.4), cold dried. The dried bacteria were mixed with $\mathrm{LiCl}(20 \mathrm{ml} 5 \mathrm{M} \mathrm{LiCl}$ per $0.1 \mathrm{~g}$ dried bacteria), shaken for $3 \mathrm{~h}$ at $37^{\circ} \mathrm{C}$, spun 6000 $\mathrm{rpm}$ at $4^{\circ} \mathrm{C}$ for $10 \mathrm{~min}$. Then, the supernatant was thoroughly dialyzed with phosphate buffered solution (pH 7.4), concentrated with PEG at $4^{\circ} \mathrm{C}$, then stored at $-20^{\circ} \mathrm{C}$ until use.

A blank MRS medium was used as control, extracted the same way as described above.

\subsubsection{Adhesion Ligand Purification (Sephadex Chromatography)}

Sephadex 50 was swollen with water, slowly packed into a column $(1.2 \times 100 \mathrm{~cm})$. The resin was then equilibrated with phosphate buffered solution $(0.01 \mathrm{~mol} / \mathrm{L}, \mathrm{pH} 7.2)$. Then, ligand preparations $(1 \mathrm{ml}$, containing $30 \mathrm{mg})$ were loaded slowly into the column, eluted with phosphate buffered solution $(0.01 \mathrm{~mol} / \mathrm{L}, \mathrm{pH} 7.2)$ at $0.2 \mathrm{ml} / \mathrm{min}$. each elution peak was collected separately and frozen until use.

\subsubsection{Identification of Adhesion Ligand}

\subsubsection{Adhesion Test}

Lactobacillus suspension $(1000 \mu \mathrm{l})$ was incubated with the primary extract $(200 \mu \mathrm{l})$ or the chromatography elutant $(200 \mu \mathrm{l})$, at $37^{\circ} \mathrm{C}$ for $24 \mathrm{~h}$ (bacterial cells were not broken). Cells were cultured on coverslips which were placed in 24-well plates (after 2 - 3 days of attachment). Then, bacteria $(200 \mu \mathrm{l})$ that were treated with the primary extract or chromatograph elutants were added to the cell culture. Three wells were used for each ligand extract. After incubation at $37^{\circ} \mathrm{C}$ for $24 \mathrm{~h}$, coverslips were picked up and washed 6 times with phosphate buffered solution (pH 7.4), dried naturally, fixed with methanol, stained with Gram stain, and examined under microscope. The number of bacteria attached to each of 50 cells was counted. Two control groups were set up. Control 1 was $200 \mu \mathrm{l}$ of bacterial suspension that was shaking washed 5 - 6 times with phosphate buffered solution. Control 2 was $200 \mu \mathrm{l}$ of normally cultured bacterial suspension. A preparation is considered Lactobacillus surface adhesion ligand if it has greater adhesion compared with control 1, and contained protein band that was similar adhesion as in control 2 [2].

\subsubsection{Discontinuous Native PAGE}

The primary and fine extracts were analyzed for molecular weight [5].

\subsubsection{Statistics Analysis}

Statistics between treatment were assessed utilizing with the ANOVA procedure and Duncan's multiple range test was used for multiple comparisons. analyze the treatment effects adherence to the cells.

\section{RESULTS}

\subsection{Extraction of Adhesion Ligand}

The adhesion ligand was isolated with two methods. The ammonium sulfate method produced $2 \mathrm{ml}$ of adhesion ligand preparation, with a protein concentration of 40 $\mathrm{mg} / \mathrm{ml}$ extracted from $5000 \mathrm{ml}$ Lactobacillus culture supernatant. The $\mathrm{LiCl}$ produced a preparation containing $31 \mathrm{mg} / \mathrm{ml}$ protein $2 \mathrm{ml}$.

\subsection{Electrophoresis Results of Primary Adhesion Ligand Extracts}

Electrophoresis results of primary adhesion ligand extracts were shown in Figures 1 and 2.

\subsection{Effect of Lactobacillus Ligand Extraction on Attachment}

Lactobacillus ligand extracts were tested for their ability to interfere with the attachment of the bacteriium to intestinal epithelial cells. The numbers of bacterial cells attached to epithelial cells as influenced by the extracts were shown in Table 1.

Compared with control 1, ligand prepared with ammonium sulfate method and with $\mathrm{LiCl}$ method significantly increased the ability of Lactobacillus adhering to 


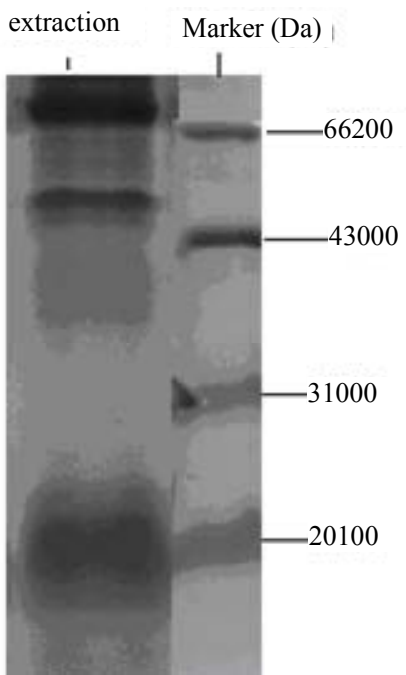

Figure 1. Native gel electrophoresis results of adhesion ligand extracted from Lactobacillus with $30 \%$ saturated ammonium sulfate.

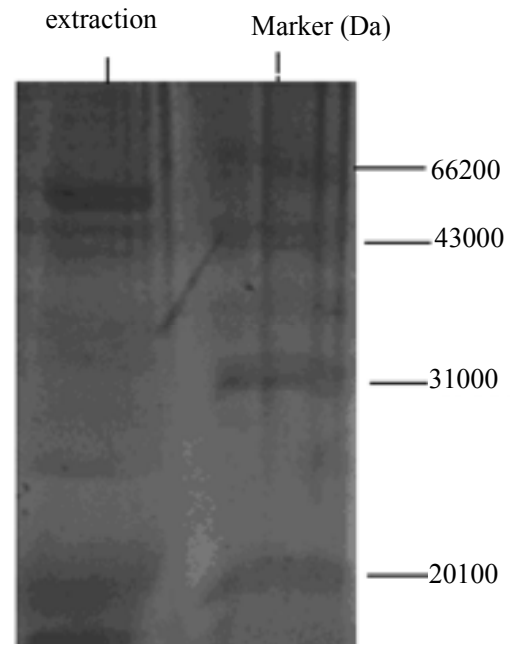

Figure 2. Native gel electrophoresis results of surface adhesion ligand extracted with $\mathrm{LiCl}$ from Lactobacillus.

Table 1. Effect of adhesion ligand preparation on the attachment of Lactobacillus to intestinal epithelial cells.

\begin{tabular}{cc}
\hline Method & $\begin{array}{c}\text { Number of Lactobacillus adhered } \\
\text { (entries/cell) }\end{array}$ \\
\hline $30 \%\left(\mathrm{NH}_{4}\right)_{2} \mathrm{SO}_{4}$ & $20.70 \pm 1.48^{\mathrm{a}}$ \\
$\mathrm{LiCl}$ & $14.30 \pm 1.87^{\mathrm{b}}$ \\
Control 1 & $3.00 \pm 0.61^{\mathrm{c}}$ \\
Control 2 & $19.80 \pm 1.97^{\mathrm{a}}$ \\
\hline
\end{tabular}

Note: Values that were marked with different superscripts were significantly different from each other $(P<0.01)$.

intestinal epithelial cells. Compared with control 2, the numbers of attached bacteria were similar, suggesting that the primary extract contained the ligand, but need further purification. The ammonium preparation displayed greater adhesion ability.

\subsection{Purification of Adhesion Ligand}

After sephadex 50 chromatography, three broad peaks were clearly seen (Figures 3 and 4). Each peak was collected in $5 \mathrm{ml}$ elutant.

\subsection{Adhesion Test}

After sephadex 50 chromatography purification, the adhesion ligand preparations were tested for their influence on the attachment of Lactobacillus to intestinal epithelial cells. Results were shown in Tables 2 and 3.

Table 1 showed that the second peak elutant of the ammonium sulfate extract increased the ability of Lactobacillus adhering to intestinal epithelial cells, compared with control 1 , but had similar adhesion ability compared with control 2 . These results suggest that the peak 2 elutant is the purified adhesion ligand.

The peak 2 elutant of the $\mathrm{LiCl}$ extract displayed a

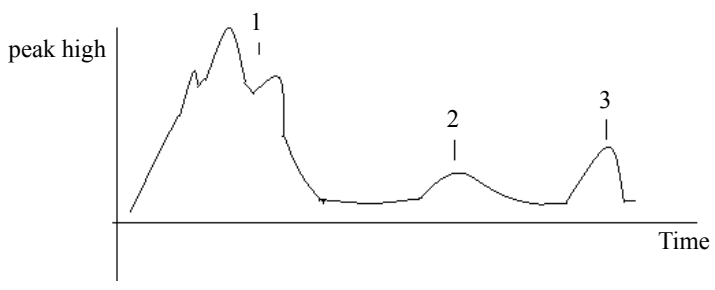

Figure 3. Chromatography profile of adhesion ligand from Lactobalcillus prepared with $30 \%$ saturated ammonium sulfate.

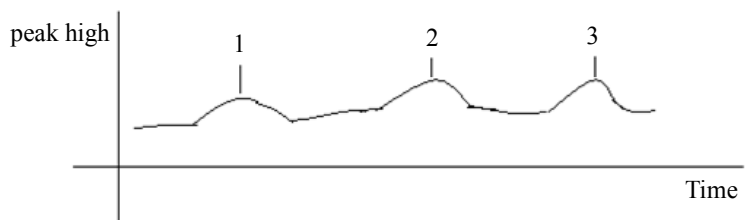

Figure 4. Chromatography profile of adhesion ligand from Lactobalcillus prepared with $\mathrm{LiCl}$.

Table 2. Effect of adhesion ligand preparations obtained by ammonium sulfate extraction followed by chromatography on the number of Lactobacillus adhered to intestinal epithelial cells.

\begin{tabular}{cc}
\hline Peak & $\begin{array}{c}\text { Number of Lactobacillus } \\
\text { adhered (entries/cell) }\end{array}$ \\
\hline 1 & $7.40 \pm 1.23^{\mathrm{b}}$ \\
2 & $20.70 \pm 1.45^{\mathrm{a}}$ \\
3 & $6.70 \pm 1.45^{\mathrm{b}}$ \\
Control 1 & $4.00 \pm 0.76^{\mathrm{b}}$ \\
Control 2 & $21.89 \pm 1.32^{\mathrm{a}}$ \\
\hline
\end{tabular}

Note: Values that were marked with different superscripts were significantly different from each other $(P<0.01)$. 
Table 3. Effect of adhesion ligand preparations obtained by $\mathrm{LiCl}$ extraction followed by chromatography on the number of Lactobacillus adhered to intestinal epithelial cells.

\begin{tabular}{cc}
\hline Peak & $\begin{array}{c}\text { Number of Lactobacillus } \\
\text { adhered (entries/cell) }\end{array}$ \\
\hline 1 & $6.80 \pm 1.56^{\mathrm{a}}$ \\
2 & $19.60 \pm 1.89^{\mathrm{b}}$ \\
3 & $5.70 \pm 1.35^{\mathrm{a}}$ \\
Control 1 & $5.00 \pm 0.98^{\mathrm{a}}$ \\
Control 2 & $21.89 \pm 1.32^{\mathrm{b}}$ \\
\hline
\end{tabular}

Note: Values that were marked with different superscripts were significantly different from each other $(P<0.01)$.

significantly higher ability to increase the adhesion of Lactobacillus to intestinal epithelial cells, compared with control 1, but a similar ability, compared with control 2 . These results suggest the peak 2 contained the purified adhesion ligand.

Native gel electrophoresis analysis of the elutants isolated from ammonium sulfate extract and $\mathrm{LiCl}$ extract indicated that the active ingredient was in the second peak.

\subsection{Molecular Weights of the Two Adhesion Ligand Isolates}

Molecular weights of the two adhesion ligand isolates were shown in Figure 5. The two adhesion ligand preparations were subjected to discontinuous native polyacrylamide gel electrophoresis analysis and molecular weights of the ligand preparations were determined to be $43-66 \mathrm{KDa}$.

\section{DISCUSSION}

Results from the current study demonstrated that chicken Lactobacillus adhesion ligand has a molecular weight 43 - $66 \mathrm{KDa}$. This molecular weight is similar to that (about $45 \mathrm{KDa}$ ) reported by Greene (1994) [6], and that (30 - 70 KDa) reported by Henriksson (1996) [1], but very different from that (14 - $23 \mathrm{KDa})$ reported by Zheng (1999) for Bifidobacterium [2]. Avall-Jaaskelainen (2003) reported that the adhesion protein from Lactococcus lactis is $111 \mathrm{Kda}$ [7]. These reports indicate that the molecular weights of adhesion proteins from Lactococcus, Bifidobacterium and Lactobacillus are very different [8-13]. Further studies are necessary in this field.

It is difficult and time-consuming to purify surface adhesion ligand from chicken Lactobacillus with column chromatography. A large column chromatography system is needed for the preparation. Very little amount of purified protein can be obtained from one run. Thus a simple and effective method is needed. The current study showed that the $25 \%$ ammonium sulfate method pro-

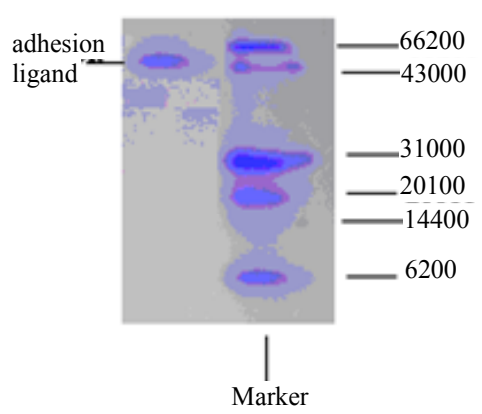

Figure 5. Discontinuous native gel lectrophoresis of adhesion ligand from Lactobacillus A.

duced more and purer surface adhesion ligand than did $\mathrm{LiCl}$ method. Future work may employ the ammonium sulfate method to prepare purer protein.

The current study used sephadex 50 to isolate protein, substituting the cumbersome molecular sieve and ion exchange chromatography method. The method used in this study ideally purified the surface adhesion ligand of Lactobacillus from primary extract.

It is important to determine whether there is adhesion protein from normal bacteria that interact with intestinal epithelial cells. This will help the further application of this protein to enhance the ability of normal bacteria to attach to intestinal epithelial cells, help the elucidation of mechanism involved in adhesion.

In the adhesion test of this study, bacteria were incubated at $37^{\circ} \mathrm{C}$ for $24 \mathrm{~h}$. Electron microscopy analysis indicated that the bacterial cells were intact after incubation, imposed no adverse effect on the results of the experiment.

\section{CONCLUSION}

We got the Lactobacillus adhesion ligand adhering to the intestinal epithelial cells by ammonium sulfate and $\mathrm{LiCl}$ extraction, sephadex chromatography purification methods. The purified adhesion ligand molecular weight was $43-66 \mathrm{KDa}$.

\section{ACKNOWLEDGEMENTS}

This work was supported by the ministry of Agriculture of China: the earmarked fund for Modern Agro-Industry Technology Research System of China and natural science fund of China (31072050).

\section{REFERENCES}

[1] Henriksson, A. and Conway, P.L. (1996) Adhesion of Lactobacillus fermentum 104-S to porcine stomach mucus. Current Microbiology, 33, 31-34. doi:10.1007/s002849900069

[2] Zheng, Y.J., Ling, J., Wang, L.S., et al. (1999) Purification of Bacillus bifidus adhesion ligand. Journal of Mi- 
crobiology and Immunology of China, 19, 196.

[3] Turner, M.S., Peter, T. and Louisem, H. (1997) Identification and characterization of a basic cell surface-located protein from Lactobacillus fermentum BR11. Journal of Bacteriology, 179, 3310-3316.

[4] Takahiro, T., Ritva, V., Benita, W., et al. (1995) A collagen-binding S-Layer protein in Lactobacillus crispatus. Applied and Environmental Microbiology, 61, 2467-2471.

[5] Wang, J.Z. and Fan, M. (2002) Protein technical manual. Science Publishing Company, Beijing.

[6] Greene, J.D. and Klaenhammer, T.R. (1994) Factors involed in adherence of Lactobacilli to human $\mathrm{CaCo}-2$ cells. Applied and Environmental Microbiology, 60, 4487-4494.

[7] Avall-Jaaskelainen, S., Lindholm, A. and Palva, A. (2003) Surface display of the receptor-binding region of the Lactobacillus brevis S-Layer protein in Lactococcus lactis provides nonadhesive Lactococci with the ability to adhere to intestinal epithelial cells. Applied and Environmental Microbiology, 69, 2230-2236. doi:10.1128/AEM.69.4.2230-2236.2003

[8] Bernet, M.F., Brassart, D. and Neeser, J.R. (1994) Lac- tobacillus acidophilus LA 1 binds to cultured intestinal cell Lines and inhibits cell attachment cell invasion by enterovirulen. Bacteria Gut, 35, 483-489.

[9] Zhao, B. and He, S.J. (2002) Microbiology test. Science Publishing Company, Beijing.

[10] Jacobs, A.A., Venema, J. and Leeven, R. (1987) Inhibition of adhesive activity of K88 fibrillae by peptides derived from the K88 adhesin. Journal of Bacteriology, 169, 735-741.

[11] Rubinsztein-Dunlop, S., Guy, B., Lissolo, L. and Fischer, H. (2005) Identification of two new Helicobacter pylori surface proteins involved in attachment to epithelial cell lines. Journal of Medical Microbiology, 54, 427-434. doi:10.1099/jmm.0.45921-0

[12] Shan, K. and Zhe, T. (2000) One method of quickly SDSPAGE electrophoresis dyeing bleach which profit for protein reclaim. Progress in Biochemistry and Biophysics $B$, 27, 210-211.

[13] Shandong Agriculture University (2002) Biochemistry and molecular biological test technology. Shandong Publishing Company, Tai'an. 